\title{
Presidential Report to the Congress: Net Benefit Analysis of US/Soviet Arms Control
}

\section{David Hafemeister}

Physics Department, California Polytechnic State University, San Luis Obipso, CA, USA

A net assessment of the benefits/losses of arms control treaties in terms of military significance was required in response to the START Resolution of Ratification. The response by the Executive Branch belabored smaller issues, avoided accomplishments and didn't carry out the net assessment.

The Cold War seems like a distant memory. However, issues remain that should be studied if we do not wish to relive history. How much did arms control keep the peace between the U.S.A. and the Soviet Union? Did the arms control process pave the way to end the Cold War peacefully? Did the Soviet Union comply with arms control treaties? Was the U.S. compliance process a meaningful, truthful exercise? Were the Soviet violations militarily significant? What was the net assessment in terms of military significance between violations on arms control treaties and arms reductions pursuant to arms control treaties? Was the "effective verification" standard sufficient to protect the U.S. national security? ${ }^{1}$ These are large questions, which we will only partially answer. The framework for this article was established during 1990-1992 when Bill Ashworth and I were the two majority professional staff members at the Senate Foreign Relations Committee (SFRC), which were appointed to examine arms control treaties at the end of the Cold War. ${ }^{2}$

In a previous occasional report to Science \& Global Security, I examined the robustness of the U.S. triad and the ability of Soviet defenses to oppose the triad. ${ }^{3}$ The primary reference was an eight-volume, classified study by the Government Accounting Office, widely thought to be the best such study, and the follow-up unclassified Senate hearings. ${ }^{4}$ In this occasional report, we 
examine the issue framed by the SFRC in its Condition Seven of the STARTI Resolution of Ratification. Condition Seven required the President to carry out a net assessment analysis on the good and bad impacts of arms control treaties. Losses from arms control treaties come from noncompliance to the arms control treaties. The benefits of arms control treaties come from the reduction of nuclear weapons, the removal of destabilizing weapons or tactics, and the establishment of cooperative measures to increase stability between the superpowers. Condition Seven requires the assessment be carried out in terms of military significance, namely the threat to U.S. nuclear forces.

The efficacy of arms control treaties was hotly debated before the SFRC. One side believed that arms control gave a predictable future that would avoid irrational actions. The other side, championed by the Ranking Minority Member, Senator Jesse Helms, believed that Soviets would massively cheat to threaten U.S. national security. The SFRC national security staff was convinced that the importance of this issue warranted a serious analysis by the executive branch at the end of the Cold War. With this in mind, it was decided that a condition requiring a presidential report was needed to shed light on the issue.

\section{MODUS OPPORENDI}

Section I below displays Condition Seven and the SFRC report language that supported it. This is followed in Section II with a description of the Report to the Congress on Treaty Compliance. Because of space limitations we examine only the analysis of the INF treaty, and not the SALT agreements because they are too old, and not the START treaty because it had not entered into force at the time of the March 1993 presidential report. Section III is our conclusion on the adequacy of the presidential response.

\section{I.A. SENATE CONDITION SEVEN ON TREATY COMPLIANCE ${ }^{5}$}

Within 180 days of the Senate's giving its advice and consent to ratification of the treaty, the President shall submit to the Senate an updated and expanded compliance report in classified and unclassified form, setting forth-

(A) a listing and discussion of the actions which are violations or probable violations of the obligations of the SALT I Interim Agreement, SALT II, ABM, INF and START Treaties, and the ultimate resolution of these issues;

(B) a listing and discussion of the actions which are in compliance with the SALT I Interim Agreement, SALT II, ABM, INF and START Treaties; and

(C) a comparison of the military significance of those actions listed in subparagraphs (A) and (B). 


\section{I.B. SENATE REPORT ON CONDITION SEVEN 6}

The degree of Soviet noncompliance has been widely debated over the years. Condition Seven of the Resolution of Ratification requires a compliance report on all the major acts of compliance and noncompliance by the former Soviet Union and its successor states. Our future relations with the successor states on arms control treaties will, of course, continue to be addressed in the report called for in Section 52 of the Arms Control and Disarmament Act.

Condition Seven calls for expanded and updated compliance report that could well be the last such noncompliance report on the disbanded Soviet Union. This report calls for listing of all significant Soviet and successor states violations and probable violations of the SALT I Interim Agreement, SALT II, ABM, INF and START treaties. This listing shall be accompanied with a discussion of the ultimate resolution of these issues. Second, Condition Seven requires a listing of the significant acts of compliance to these arms control treaties by the former Soviet Union, and the successor states. This list shall contain the numbers and types of systems eliminated, such as silos, missiles, and launchers. In addition, this report shall list the aggregate numbers of inspections and notifications that were carried out without any problems, as well as any for which there were difficulties. Lastly the report calls for a comparison of the military significance of the acts in noncompliance as compared to the acts of compliance.

In the committee's view, the arms control process with the Soviets and their successors, on balance, has paved the way towards the reductions in the START Treaty and the deeper reductions in the prospective de-MIRVing Treaty. The report required in Condition Seven serves as a useful adjunct when considering the net benefit of arms control agreements with the former Soviets.

The committee therefore recommends a condition requiring the submission of a Presidential Report on Treaty Compliance and the Military Significance of Treaty Violations within 180 days of the Senate's giving its advice and consent to the ratification of the START Treaty. This updated and expanded compliance report will differ from annual Pell report (Section 52 of the ACDA Act) by listing all the actions of compliance and all the actions of past violation, or probable past violation, and then comparing the military significance of these two kinds of actions.

\section{PRESIDENTIAL REPORT OF MARCH 1993}

The Presidential Report consisted of one page of introduction, 11 pages on violations, 2.3 pages on acts of compliance, and 1.3 pages on a net assessment. The most clear-cut violations listed were as follows: The Krasnoyarsk radar (which was to be converted into a furniture factory) was a clear-cut violation to the ABM Treaty, but it was not militarily significant in a capacity to help shoot down U.S. ICBMs. The second "new type missile" (the SS-25) was a violation 
to the START II Agreement. Condition Seven did not address nuclear testing, but if it had, it should have discussed the history of the "likely violation" of the Threshold Test Ban Treat (TTBT). This charge was removed in 1990 after the 1988 CORRTEX measurements at Semipalatinsk Test Site and after properly taking into account the geological differences between test sites. ${ }^{7}$ The U.S. record on TTBT noncompliance charges was not entirely honorable.

\section{II.A. VIOLATIONS TO THE INF TREATY (EXCERPTS FROM THE PRESIDENTIAL REPORT)}

1. Transits of Missiles on Launchers. The intermediate-range missiles may be carried on their launchers only at repair or elimination facilities and not so carried for transit to other locations. The Soviets had notified the U.S. of nearly 200 such transits to fulfill the terms of the INF treaty. After discussions in the Special Verification Commission, the Soviets changed their transit practices.

2. Non-declared Treaty-Limited Items. In the summer of 1988 the Soviets had some errors in their data in the Memorandum of Understanding, which they corrected.

3. Un-notified Movements of Training Launchers. There was a disagreement on whether notification was necessary for moving training launchers. The Soviets later agreed to do this.

4. Missiles at an Elimination Facility. Two SS-12 missiles that should have been removed were discovered at the Saryozek Main Operating Base.

5. Missiles at Non-declared Locations. For brief times, some SS-20 missiles and launchers were parked outside of two launch-to-destruction elimination sites. The boundaries of the two sites were redrawn since these were parked at these locations as a temporary convenience.

6. Cargoscan. For 10 days in March 1990 the Soviets refused to allow Cargoscan to $x$-ray image missiles the Votkinsk missile factory exit portal. The Soviets had objections to U.S. procedures, which were then modified for Soviet acceptance.

\section{II.B. PROBABLE VIOLATION TO THE INF TREATY}

SS-23 Missiles: Article I of the INF Treaty provides that each party shall eliminate all "its" intermediate-range and shorter-range missiles and not have such systems thereafter. Article V repeats the requirement that each Party eliminate all "its" shorter-range missiles of the categories "listed in the Memorandum of Understanding..." Article VI contains a prohibition against producing or 
flight-testing any intermediate-range or shorter-range missiles. Read together, these provisions in effect also contain a prohibition on transfer of treaty-limited items after Treaty signature: each Party must destroy all of its intermediaterange and shorter-range missiles and may not produce any such missiles in the future for any purpose, including transfer.

In early 1990, when the German Democratic Republic (GDR) publicly stated that it was eliminating SS-23 missiles located there, the United States became aware for the first time of the existence of SS-23 missiles in three Eastern European countries. The Soviet Union stated they transferred SS-23s to the GDR, Czechoslovakia, and Bulgaria, prior to entry into force of the INF Treaty. None of these three countries is a party to the INF Treaty. SS-23 missiles are shorter-range missiles that are listed in the INF Treaty. Soviet SS-23 missiles were to have been eliminated by November 1, 1989.

The issue of whether the existence of these SS-23 missiles violated the INF Treaty was first examined and reported in the February 1991 President's Noncompliance Report. In September 1991, the U.S. Arms Control and Disarmament Agency submitted a Supplemental Report to Congress on SS-23 Missiles in Eastern Europe. That Supplemental Report stated the finding that the Soviet Union:

had understandings that constituted what amounted to an undisclosed program of cooperation. Thus, the United States has reaffirmed its previous finding that the Soviet Union negotiated in bad faith. The United States further found that the Soviet Union has probably violated the Elimination Protocol of the Treaty by failing to eliminate in accordance with Treaty procedures, re-entry vehicles associated with and released from programs of cooperation.

\section{II.C. ACTIONS TAKEN TO COMPLY TO THE INF TREATY}

The Soviet Union eliminated all its declared INF Treaty limited items (TLI) and facilities under strict verification by the United States. Since the last report, the Soviet Union and new states of the former Soviet Union continued to allow the United States to exercise its inspection rights contained in the INF Treaty. These inspections included the presence of the United States' continuous monitoring inspection site at Votkinsk, Russian Federation; and the conduct of on-site inspections by the United States.

\section{II.D. NET ASSESSMENT ON THE INF TREATY}

Prior to the signing of the INF Treaty, serious concerns existed within the United States and among our allies concerning the threat posed by Soviet INF systems-particularly the mobile SS-20 missile. Under the INF Treaty, the Soviet Union eliminated all its declared INF Treaty limited items (TLI) and 
facilities under strict verification by the United States. The United States is concerned over the continued existence of the SS-23 missiles in Eastern Europe and continues to pursue their destruction in order to fulfill the objective of the INF Treaty to eliminate this class of missiles. On balance, however, the achievements of the INF Treaty have strengthened western security.

\section{ANALYSIS OF THE PRESIDENTIAL REPORT}

The Presidential Report on noncompliance is made up of poor scholarship and errors of omission. The length of Presidential Report was divided as follows: violations (4 pages), compliant acts (0.2 pages), net assessment analysis (0.2 pages). Thus, violations got twenty times the space, compared to compliant acts and compared to the net assessment analysis. This is particularly shameful because greater analysis already existed in the published SFRC Report on the START Treaty, which is given below.

\section{III.A. VIOLATIONS OF THE INF TREATY}

\section{SS-23 Issue in SFRC START Report ${ }^{8}$}

The issue of undeclared the Soviet-manufactured SS-23s located in Eastern Europe has been addressed in a separate report (September 19, 1991) to the Congress. The Soviets had not declared the 72 SS-23 missiles involved in the programs of cooperation with the German Democratic Republic, Bulgaria and Czechoslovakia. Unfortunately, the U.S. had not asked about these kinds of programs during the negotiation of the INF Treaty, partly because the U.S. did not wish to discuss the situation of the Pershing-I missiles that were owned (and later destroyed) by the Federal Republic of Germany. The Pershing-I systems were under the joint control of the FRG and the U.S.

In a response to a question by Senator Pressler on the ultimate disposition of the SS-23s, the Administration stated:

German, Czech and Slovak federal governments have indicated that the missiles in their possession would be destroyed when technical and environmental matters were resolved. Bulgaria, however has made conflicting statements on whether it will destroy its missiles. While continuing to press for destruction of the SS-23s, it is not in our interests to the delay reaping the benefits of START pending SS-23 destruction.

\section{CONCLUSION ON INF VIOLATIONS}

The six violations to the INF Treaty listed in the Presidential Report were not militarily significant. The issues raised were mostly a matter of sloppiness on 
the Soviet side and some disagreement as to procedures. The INF Treaty was very complicated to administer. This was particularly difficult for the decaying Soviet Union in 1988 to 1991 . Because of these procedural problems on the INF Treaty, the START Treaty gave more certainty by growing to 280 pages, plus considerable auxiliary documents. The issue of the probable violation of SS-23 missiles was discussed in more detail in the SFRC START Report, which was available to the Executive Branch, than in the Presidential report. The SS-23 issue is confusing because the U.S. had a similar situation at the time of the negotiation, namely weapon systems shared with its ally Germany.

\section{III.B. ACTS OF COMPLIANCE TO THE INF TREATY}

\section{INF Compliance Data in START Report, but Neglected in the Presidential Report ${ }^{9}$}

As of May 31, 1991, the Soviet Union eliminated all of its declared intermediate range missiles and launchers, and all of its declared shorter-range missiles and launchers. Pursuant to the INF Treaty, the Soviets eliminated 1,846 missiles with the capability to carry 3,154 warheads, and it destroyed 825 launchers.

5 SS-5 missiles;

654 SS-20 missiles (3 warheads each);

509 SS-20 lauchers;

149 SS-4 missiles;

72 SS-4 launchers;

718 SS-12 missiles;

132 SS-12 launchers;

239 SS-23 missiles;

106 SS-23 launchers;

80 SSC-X-4 missiles;

6 SSC-X-4 launchers.

\section{CONCLUSION ON INF COMPLIANT ACTS}

The Presidential Report states only that the "Soviet Union eliminated all its declared INF Treaty limited items and facilities under strict verification by the United States." This meager answer does not give the readily available data 
listed above from the SFRC report. In addition, the Presidential Report did not give the required information on inspections.

\section{III.C. NET ASSESSMENT ON THE INF TREATY}

Senate Report Language entitled the required report as the Presidential Report on Treaty Compliance and the Military Significance of Treaty Violations. As an indictor of what the report became, the executive branch removed the Presidential authorship and reduced the scope by deleting Military Significance of Treaty Violations. The final report was merely named the Report to Congress on Treaty Compliance. The 0.2 pages of net benefit analysis in the Presidential Report primarily discuss the SS-23 situation. By 1993, the Soviets had lost control of its allies for four years, as the Berlin Wall fell on November 9, 1989.

The Presidential Report addressed the net assessment issue with but one sentence, "On balance, however, the achievements of the INF Treaty have strengthened western security." This cursory answer does not tell the Congress the military significance of the Soviet Union eliminating all of its declared intermediate range missiles and launchers, and all of its declared shorter-range missiles and launchers. Pursuant to the INF Treaty, the Soviets eliminated 1,846 missiles with the capability to carry 3,154 warheads, and it destroyed 825 launchers. The cursory answer does not give the military significance of the six INF violations and the one probable violation.

The Presidential Report should have informed us that the number of Soviet removed warheads $(3,154)$ is over three times the number of U.S. removed warheads (856). In addition, the Presidential Report should have given estimates of the effectiveness of these warheads on allied targets. Such a quantitative analysis was carried out on page 52 of the Senate Report on START, which used an exchange model to determine survivable forces, with and without violations.

There is a strange lesson to be learned here. It should be clear to most readers that the INF Treaty was necessary to end the Cold War peacefully. Without the INF Treaty, it is unlikely that the Conventional Forces in Europe (CFE) Treaty would have allowed reductions in conventional arms. Without CFE, there would not have been START, thus making the ending of the Cold War more difficult. The authors of the Presidential Report did not want to make these kinds of positive statements on arms control, nor did they give the specific accomplishments of arms control. This is an important lesson for historians and future leaders.

\section{NOTES AND REFERENCES}

1. U.S. Senate Foreign Relations Committee, The START Treaty, Executive Report 102-53, 1992, pp. 27. During hearings on the INF treaty, former Ambassador Paul Nitze defined effective verification in the following way: 'if the other side moves beyond the 
limits of the treaty in any militarily significant way, we would be able to detect such violation in time to respond effectively and thereby deny the other side the benefit of the violation.' Thus, any militarily significant cheating must be detected in a timely manner before it can threaten national security. During the 1992 ratification hearings on START I, Secretary of State James A. Baker III repeated this definition, but added a new criterion: 'Additionally, the verification regime should enable us to detect patterns of marginal violations that do not present immediate risk to U.S. security.'

2. During 1990 to 1992 this encompassed 50 hearings on arms control matters, ratification of four treaties (START, TTBT, PNET, CFE), oversight on four treaties (ABM, CWC, BWC, Open Skies), ACDA authorizations, Nunn-Lugar programs, Mitchell-Hatfield precursor to the CTBT, Glenn-Pell precursor to the 1994 Nuclear Proliferation Prevention Act, and oversight on proliferation matters relating to the Gulf War of 1991.

3. D. Hafemeister, "Reflections on the GAO Report on the Nuclear Triad," Science \& Global Security Vol. 6 (1997): 383-393.

4. U.S. Senate Governmental Affairs Committee, Evaluation of the U.S. Strategic Triad, Senate Hearing 103-457, (1994). U.S. General Accounting Office, The U.S. Nuclear Triad: GAO's Evaluation of the Strategic Modernization Program (plus eight classified volumes), GAO/T-PEMD-93-5 (1993).

5. U.S. Senate Foreign Relations Committee, The START Treaty, Executive Report 102-53 (1992), pp. 100.

6. Ibid, pp. 90-91.

7. As the technical-lead for the State Department on nuclear testing during 1987, I observed the following: The Executive Branch Interagency Committee split 3 to 3 on whether the Soviets had probably violated the TTBT. State, DOE, and CIA did not believe the TTBT was probably violated, while ACDA, JCS, and OSD believed there was a probable violation. The issue came down to the value of the bias factor between the Nevada and Semipalitinsk test sites. The bias value used in 1987 was much too low. The higher value of the bias factor determined by geophysicists Jack Evernden and Lynn Sykes was later vindicated. It took CORRTEX measurements to make the political shift from noncompliance to compliance. This should not have been necessary in a more scientifically open environment. President Reagan broke the tie in 1987 by charging the Soviets with a "likely" violation, and President George H. Bush reversed that decision in 1990. I believe the 1987 process was politicized, to take pressure from the U.S. to follow Mikhail Gorbachev's call for a complete ban on nuclear testing.

8. SFRC, pp. 63.

9. Ibid, pp. 64 . 